\title{
Transport of neutral amino acids and penicillin formation in Penicillium chrysogenum
}

\author{
Rosa del Carmen Mateos and Sergio Sanchez* \\ Departamento de Biotecnologia del Instituto de Investigaciones Biomedicas, Universidad Nacional Autonoma de Mexico, \\ Apartado Postal 70228, Mexico DF 04510, Mexico
}

(Received 7 November 1989; revised 1 March 1990; accepted 17 May 1990)

\begin{abstract}
The production of penicillin was inhibited by neutral amino acids in a resting cell system of Penicillium chrysogenum with cycloheximide. The inhibitory action was prevented by preincubation with glutathione, even though this stimulated uptake of the neutral amino acid glutamine. Chromatographic analysis of extracts obtained from cells incubated with labelled glutamine revealed that radioactivity was taken up through the formation of two intermediates; $L$ - $\gamma$-glutamyl-L-glutamine and $\delta$-(L- $\alpha$-aminoadipyl)-L-glutamine. In a resting cell system prepared from cultures previously grown in the presence of $50 \mathrm{mM}-\mathrm{L}$-lysine, a condition which restrains $\alpha$-aminoadipate and penicillin formation, uptake of glutamine was $80 \%$ inhibited. We propose that the penicillin precursor $\delta$-(L- $\alpha$-aminoadipyl)-L-cysteinyl-D-valine, which is structurally related to glutathione, is also utilized in the uptake of neutral amino acids.
\end{abstract}

\section{Introduction}

Glutamine is not only a precursor in the synthesis of primary and secondary metabolites, but also a key regulator in the synthesis and degradation of several enzymes and other compounds (Marzluf \& Fu, 1988; Mora $e t$ al., 1988). The regulation of penicillin formation by nitrogen compounds has recently received much attention (Sanchez et al., 1988), and glutamine has been reported to inhibit the formation of penicillin in a resting-cell system of Penicillium chrysogenum with cycloheximide. The addition of $1 \mathrm{~mm}$-glutathione (GSH) prevented this inhibition but did not cause a reduction of glutamine uptake (Mateos et al., 1984). The extent of this inhibition was related neither to the availability of the amino acid precursors of the antibiotic moiety, nor to the changes in activity of $\delta$-(L- $\alpha$-aminoadipyl $)-L$-cysteine synthetase, thought to be the first enzyme of the penicillin formation pathway, although recent studies suggest that $\delta$-(L- $\alpha$-aminoadipyl)-L-cysteinyl-D-valine synthetase is the first enzyme in penicillin formation in other micro-organisms (Banko et al., 1987; Van Liempt et al., 1989). The present report examines further physiological effects of glutamine on penicillin formation, and the basis of the GSH effect.

\footnotetext{
Abbreviations: GSH, glutathione; ACV, $\delta$-(L- $\alpha$-aminoadipyl)L-cysteinyl-D-valine.
}

\section{Methods}

Organism and cultivation. P. chrysogenum NRRL 1951 was kindly supplied by the Agricultural Research Service Culture Collection, Northern Regional Research Laboratory, Peoria, Ill., USA. All fermentations were done in a defined medium (DM) as previously reported (Lara et al., 1982).

Resting cell system studies. A $36 \mathrm{~h}$ culture $(25 \mathrm{ml})$ was harvested, washed with 2 vols sterile distilled water, and resuspended in $25 \mathrm{ml}$ of antibiotic formation medium (AFM) (Mateos et al., 1984). Under these conditions, cells produced penicillin linearly during $36 \mathrm{~h}$ in the presence of cycloheximide $\left(100 \mu \mathrm{g} \mathrm{m}^{-1}\right)$, without increasing in dry weight.

Penicillin assay. Penicillin was determined at specified times according to Lara et al. (1982), using benzylpenicillin as a standard.

Determination of glutamine transport. One millilitre of $\mathrm{L}-\left[\mathrm{U}-{ }^{14} \mathrm{C}\right] \mathrm{gluta}$ mine $\left(1.68 \mu \mathrm{Ci} \mathrm{mmol}^{-1} \mathrm{ml}^{-1} ; 62.2 \mathrm{kBq} \mathrm{mmol}^{-1} \mathrm{ml}^{-1}\right)$ was added to $24 \mathrm{ml}$ of a resting cell system with cycloheximide $\left(100 \mu \mathrm{g} \mathrm{ml}^{-1}\right)$ and samples were analysed at specified times.

Separation of peptides and amino acids. Intracellular peptides and amino acids were extracted by homogenizing mycelia (from $25 \mathrm{ml}$ of a resting cell system) with $10 \mathrm{ml} 80 \%(\mathrm{v} / \mathrm{v})$ ethanol as reported by Espin et al. (1979). Soluble peptides and amino acids (10 $\mu 1$ samples) were separated by two-dimensional thin-layer chromatography (A, 1-propanol/ $\mathrm{NH}_{4} \mathrm{OH} 85: 37, \mathrm{v} / \mathrm{v}$; and $\mathrm{B}$, phenol/water $80: 20, \mathrm{v} / \mathrm{v}$ ) according to Brenner et al. (1969). After separation, the chromatograms were visualized with ninhydrin reagent. When labelled glutamine was used, the spots were cut out from the chromatographic plates, and their radioactivity was estimated by scintillation counting. 
Reproducibility of results. The experiments reported were repeated at least once (two independent experiments) in duplicate and the results reported are the mean values. The observed variations were consistently less than $10 \%$.

\section{Results}

Effect of different amino acids on antibiotic formation

In a resting cell system with cycloheximide, cells of $P$. chrysogenum produced penicillin for more than $24 \mathrm{~h}$. Under these conditions, antibiotic formation was inhibited by the addition of $10 \mathrm{~mm}$-glutamine. Other neutral amino acids suppressed penicillin production to a similar extent (Table 1). On the other hand, none of the acidic or basic amino acids tested inhibited idiolite formation. The inhibitory action of neutral amino acids was prevented by preincubation of the system for $1 \mathrm{~h}$ with $1 \mathrm{~mm}$-GSH.

\section{Effect of GSH on glutamine uptake}

Considering that neutral amino acids other than glutamine also inhibited penicillin formation and that this effect was prevented by GSH, a more general mechanism was investigated as a possible cause of inhibition. For this purpose, the uptake of $\left[{ }^{14} \mathrm{C}\right]$ glutamine by cells previously incubated with GSH at different concentrations was determined (Fig. 1). Glutamine was linearly incorporated for more than $2 \mathrm{~h}$ by a resting cell system of the fungus. Preincubation with GSH stimulated glutamine uptake according to the GSH concentration used.

To explore the stimulation of glutamine uptake by GSH further, chromatographic analyses were conducted on extracts from resting cells previously incubated with $\left[{ }^{14} \mathrm{C}\right]$ glutamine. After incubation for $1 \mathrm{~h}$ with labelled glutamine (Table 2), radioactivity was taken up as L- $\gamma$-glutamyl-L-glutamine and $\delta$-L-( $\alpha$-aminoadipyl)L-glutamine. As shown in the same table, a slow increase of radioactivity was detected in the glutamine position. Chromatographic analysis of cell extracts incubated with other neutral amino acids was limited by the availability of appropriate $\gamma$-glutamyl standards.

\section{Relationship of glutamine uptake to the formation of penicillin intermediates}

The structural similarity of GSH (L- $\gamma$-glutamylL-cysteinyl-glycine) to the tripeptide intermediate of the penicillin biosynthetic pathway $\delta$-(L- $\alpha$-aminoadipyl)L-cysteinyl-D-valine (ACV), suggested a possible role of the latter in the uptake of neutral amino acids. To explore this possibility, $P$. chrysogenum was grown in the

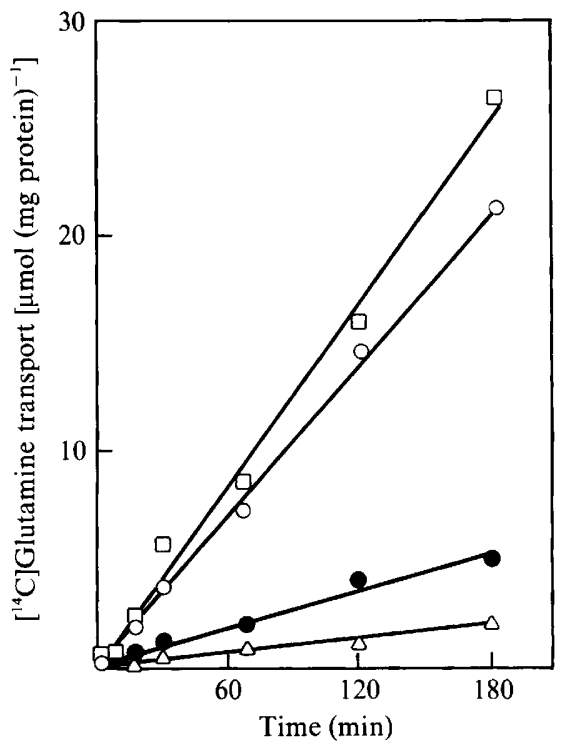

Fig. 1. Transport of $5 \mathrm{mM}-\mathrm{L}-\left[\mathrm{U}^{14} \mathrm{C}\right] \mathrm{glutamine} \quad\left(0.6 \mu \mathrm{Ci} \mathrm{mmol}^{-1}\right.$; $\left.22 \cdot 2 \mathrm{kBq} \mathrm{mmol}^{-1}\right)$ by resting cell systems previously incubated for $1 \mathrm{~h}$ with $1 \mathrm{~mm}(\bullet), 5 \mathrm{~mm}(O)$ or $10 \mathrm{~mm}(\square) \mathrm{GSH}$. $\triangle$, Control without GSH.

Table 1. Effect of several amino acids on the formation of penicillin by resting cell systems of $P$. chrysogenum with cycloheximide

Antibiotic formation was estimated after $18 \mathrm{~h}$ incubation.

\begin{tabular}{|c|c|c|}
\hline \multirow[b]{2}{*}{$\begin{array}{l}\text { Amino acid } \\
(10 \mathrm{mM})\end{array}$} & \multicolumn{2}{|c|}{ Penicillin produced $\left[\mu \mathrm{g}(\mathrm{mg} \text { protein })^{-1}\right]$} \\
\hline & By resting cells & $\begin{array}{l}\text { By resting cells } \\
\text { preincubated for } \\
1 \mathrm{~h} \text { with } 1 \mathrm{~mm}-\mathrm{GSH}\end{array}$ \\
\hline Control & 0.86 & 0.83 \\
\hline L-Alanine & 0.00 & 0.60 \\
\hline L-Arginine & 0.70 & 0.65 \\
\hline L-Asparagine & 0.00 & 0.60 \\
\hline L-Aspartate & 1.50 & 1.30 \\
\hline L-Cysteine & 0.00 & 0.65 \\
\hline Glycine & 0.00 & 0.57 \\
\hline L-Ǵlutamate & 0.82 & 0.80 \\
\hline L-Glutamine & 0.00 & 0.70 \\
\hline L-Serine & 0.00 & 0.61 \\
\hline L-Tryptophan & 0.00 & 0.61 \\
\hline L-Tyrosine & 0.00 & 0.61 \\
\hline L-Valine & 0.00 & 0.65 \\
\hline
\end{tabular}

presence of $50 \mathrm{mM}-\mathrm{L}-\mathrm{lysine}$, which inhibits the synthesis of $\alpha$-aminoadipate (Masurekar \& Demain, 1972) and so the formation of ACV. As shown in Fig. 2, the uptake of glutamine was also inhibited in resting cells of that culture. As expected, chromatographic analyses revealed the absence of $\alpha$-aminoadipate in mycelia grown in the presence of L-lysine (not shown). 


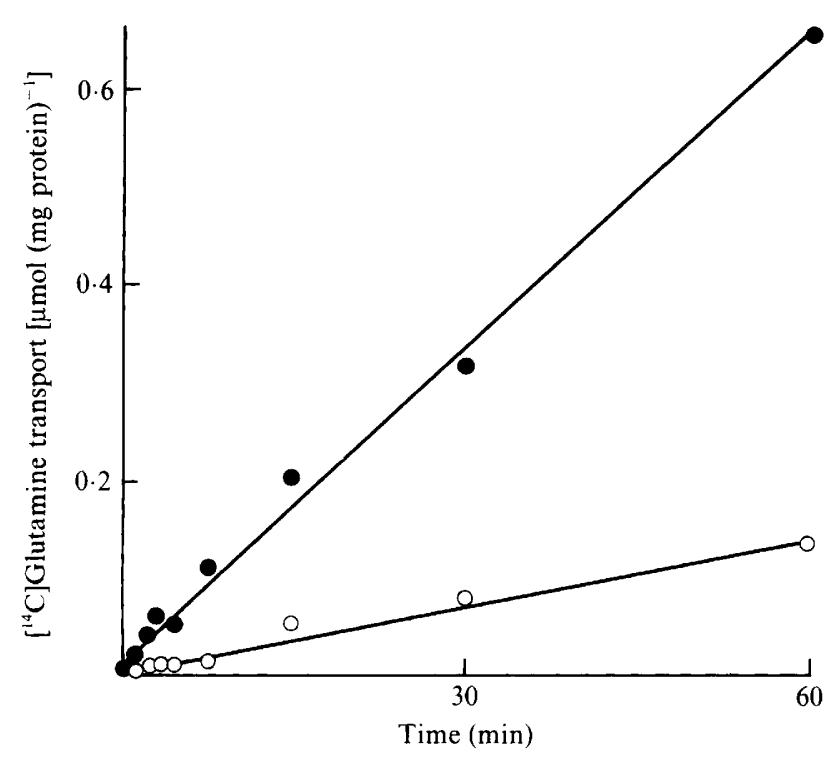

Fig. 2. Transport of $10 \mathrm{mM}-\mathrm{L}-\left[\mathrm{U}^{14} \mathrm{C}\right]$ glutamine $\left(1.68 \mu \mathrm{Ci} \mathrm{mmol}^{-1}\right.$; $62 \cdot 2 \mathrm{kBq} \mathrm{mmol}^{-1}$ ) by resting cell systems prepared from cultures

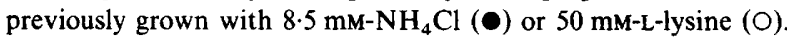

Table 2. Intracellular fate of the radioactivity from $\left[{ }^{14} \mathrm{C}\right]$ glutamine as a function of the incubation time

$A$ and $B$ are the solvent mixtures used in the two-dimensional thinlayer chromatography; see Methods.

\begin{tabular}{|c|c|c|c|c|c|c|}
\hline \multirow[b]{2}{*}{ Spot } & \multirow[b]{2}{*}{ Compound } & \multicolumn{2}{|c|}{$R_{\mathrm{F}}$ values } & \multicolumn{3}{|c|}{$\begin{array}{c}\text { Radioactivity } \\
\text { incorporated } \\
\left.\text { [c.p.m. (mg protein) })^{-1}\right]\end{array}$} \\
\hline & & $\mathrm{A}$ & B & $1 \mathrm{~h}$ & $3 \mathrm{~h}$ & $6 \mathrm{~h}$ \\
\hline A & L-Cysteine & 0.28 & 0.13 & 116 & 129 & 183 \\
\hline B & L-Glutamine & 0.49 & 0.28 & 258 & 343 & 637 \\
\hline $\mathrm{C}$ & L-Valine & 0.6 & 0.31 & 177 & 173 & 263 \\
\hline D & Glycine & 0.39 & $0 \cdot 18$ & 65 & 188 & 103 \\
\hline \multirow[t]{2}{*}{ E } & L- $\gamma$-Glutamyl- & & & & & \\
\hline & L-glutamine & $0 \cdot 3$ & $0 \cdot 19$ & 749 & 1450 & 1958 \\
\hline $\mathbf{F}$ & $\delta$-(L- $\alpha$-Aminoadipyl)- & 0.55 & 0.40 & 621 & 907 & 1790 \\
\hline
\end{tabular}

\section{Discussion}

Using a resting-cell system of $P$. chrysogenum we found that glutamine and other neutral amino acids strongly inhibit penicillin formation when used at concentrations higher than $5 \mathrm{~mm}$. The inhibitory effect on antibiotic biosynthesis was prevented by preincubation with $1 \mathrm{~mm}$-GSH through a mechanism apparently unrelated to amino acid exclusion, since GSH strongly stimulated the uptake of glutamine. It seems that GSH can mediate translocation of neutral amino acids across mammalian

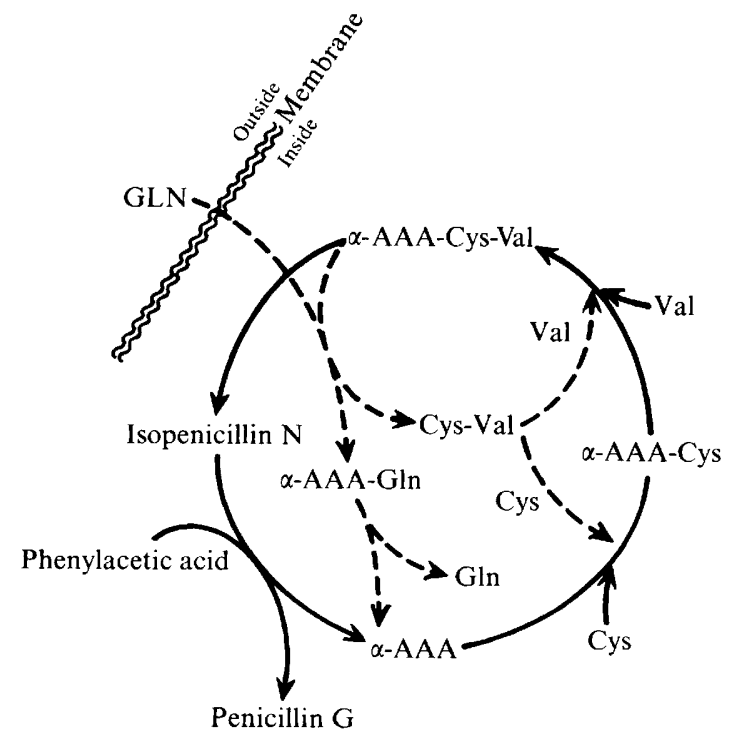

Fig. 3. Proposed model for the incorporation of neutral amino acids using an intermediate of the penicillin biosynthetic pathway. The valine molecule may assume the L-form when free, and the D-form when attached to the peptides. AAA, Aminoadipic acid.

cell membranes (Meister, 1983). This mechanism, which involves transfer of the GSH $\gamma$-glutamyl moiety to the amino acid by the action of $\gamma$-glutamyl transpeptidase, results in the formation of the $\gamma$-glutamyl amino acid derivative (Meister, 1983). This also seems to be true for the transport of neutral amino acids by resting cell systems of $P$. chrysogenum, since glutamine was taken up through the formation of two intermediates, one of which corresponded to L- $\gamma$-glutamyl-L-glutamine. Considering the structural similarity between GSH and $\mathrm{ACV}$, the tripeptide intermediate of the penicillin biosynthetic pathway, the possibility that this intermediate could be used in amino acid transport processes was envisaged as a mechanism to explain the decrease in penicillin formation caused by neutral amino acids (Fig. 3). Experimental evidence supporting this hypothesis is that L-lysine (reported to inhibit penicillin formation by Masurekar \& Demain, 1972) caused a significant reduction in the transport of glutamine (Fig. 2). Furthermore, chromatographic analysis of extracts obtained from cells incubated with labelled glutamine showed incorporation not only in the L- $\gamma$-glutamylL-glutamine position of the plate but also in another spot which corresponded to $\delta$-(L- $\alpha$-aminoadipyl)-L-glutamine. It is postulated that the valine molecule may recover the $\mathrm{L}$-form when it is free, and assume the D-form when attached either to L-cysteinyl-D-valine (Cys-Val) or to ACV $(\alpha$-AAA-Cys-Val).

Meister \& Anderson (1983) have reported that once the $\mathrm{L}-\gamma$-glutamyl-glutamine is produced, the amino acid 
is released by the action of $\gamma$-glutamyl-cyclotransferase with the concomitant formation of 5-oxoproline. This compound is a highly stable cyclized form of glutamate, and an intermediate of the $\gamma$-glutamyl cycle, which is then converted to glutamate by the action of 5-oxoprolinase (Meister \& Anderson, 1983). In agreement with our results, a cyclized form of $\alpha$-aminoadipate (6-oxopiperidine-2-carboxylate) has also been detected in the fermentation broths of $\boldsymbol{P}$. chrysogenum grown in the presence of neutral amino acids (Brundidge et al., 1980).

We thank Arnold L. Demain, Brendan Rowlands and Isabel PerezMontfort for reading the manuscript and making helpful suggestions. We are indebted to Lourival Possani and Martha Albores for the synthesis of $\delta$-(L- $\alpha$-aminoadipyl)-L-glutamine.

\section{References}

Banko, G., Demain, A. L. \& Wolf, S. (1987). $\delta$-(L- $\alpha$-Aminoadipyl)L-cysteinyl-D-valine synthetase, a multifunctional enzyme with broad substrate specificity for the synthesis of penicillin and cephalosporin precursors. Journal of the American Chemical Society 109, 2858-2861.

Brenner, M., Niederwieser, A. \& Pataki, G. (1969). Amino acids and derivatives. In Thin-Layer Chromatography, pp. 730-786. Edited by E. Stahl. New York: Springer-Verlag.
Brundidge, S. P., Gaeta, F. C. A., Hook, D. J., Sapino, C., Elander, R. P. \& MORIN, R. B. (1980). Association of 6-oxo-piperidine2-carboxylic acid with penicillin $\mathrm{V}$ production in Penicillium chrysogenum fermentations. Journal of Antibiotics 33, 1348-1351.

Espin, G., Palacios, R. \& MoRA, J. (1979). Glutamine metabolism in nitrogen-starved conidia of Neurospora crassa. Journal of General Microbiology 115, 59-68.

lara, F., Mateos, R. C., Vazquez, G. \& Sanchez, S. (1982). Induction of penicillin biosynthesis by L-glutamate in Penicillium chrysogenum. Biochemical and Biophysical Research Communications $105,172-178$

MARZLUF, G. A. \& FU, Y.-H. (1988). Genetic and metabolic regulation of nitrogen metabolism in Neurospora crassa. In Nitrogen Source Control of Microbial Processes, pp. 83-98. Edited by S. Sanchez. Boca Raton, Florida: CRC Press.

Masurekar, P. S. \& Demain, A. L. (1972). Lysine control of penicillin biosynthesis. Canadian Journal of Microbiology 18, 1045-1048.

Mateos, R. C., VazQuez, G. \& Sanchez, S. (1984). Effect of glutamine on penicillin formation in Penicillium chrysogenum. Biotechnology Letters 6, 109-114.

Meister, A. \& ANDERSON, M. E. (1983). Glutathione. Annual Review of Biochemistry 52, 711-760.

Mora, J., Calderon, J. \& Hernandez, G. (1988). Search assimilation, and turnover of nitrogen in some fungi. In Nitrogen Source Control of Microbial Processes, pp. 59-81. Edited by S. Sanchez. Boca Raton, Florida: CRC Press.

Sanchez, S., Paniagua, L., Mateos, R. C., Lara, F. \& Mora, J. (1981). Nitrogen regulation of penicillin $\mathrm{G}$ biosynthesis. In Advances in Biotechnology, vol. 3, pp. 147-154. Edited by S. Sanchez. Toronto: Pergamon Press.

SancheZ, S., Flores, M. E. \& Demain, A. L. (1988). Nitrogen control of penicillin and cephalosporin fermentations. In Nitrogen Source Control of Microbial Processes, pp. 121-136. Edited by S. Sanchez. Boca Raton, Florida: CRC Press.

VAN LIEMPT, H., Von Dobhren, H. \& KleinKauf, H. (1989). $\delta$-(L- $\alpha$-Aminoadipyl)-L-cysteinyl-D-valine synthetase from Aspergillus nidulans. Journal of Biological Chemistry 264, 3680-3684. 